\begin{tabular}{l} 
2. To: (Receiving Organization) \\
Distribution \\
\hline 5. Proj./Prog./Dept./Div.: \\
SNE Project/W-441 \\
\hline 8. Originator Remarks: \\
For approval and release.
\end{tabular}

2. To: (Receiving Organization)

Distribution

Eor approval and release.

11. Receiver Remarks:

3. From: (Originating Organization)
Techni cal Integration
6. Design Authority/Design Agent/Cog. Engr.:
C. C. Pitkoff

3. From: (Originating Organization)

C. C. Pitkoff

11A. Design Baseline Document? $\bigcirc$ Yes

No

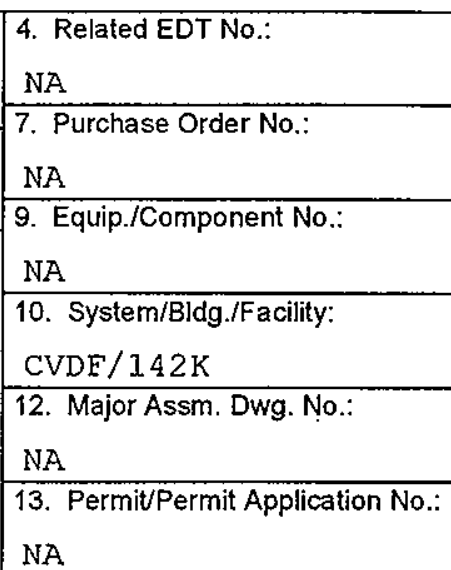

14. Required Response Date:

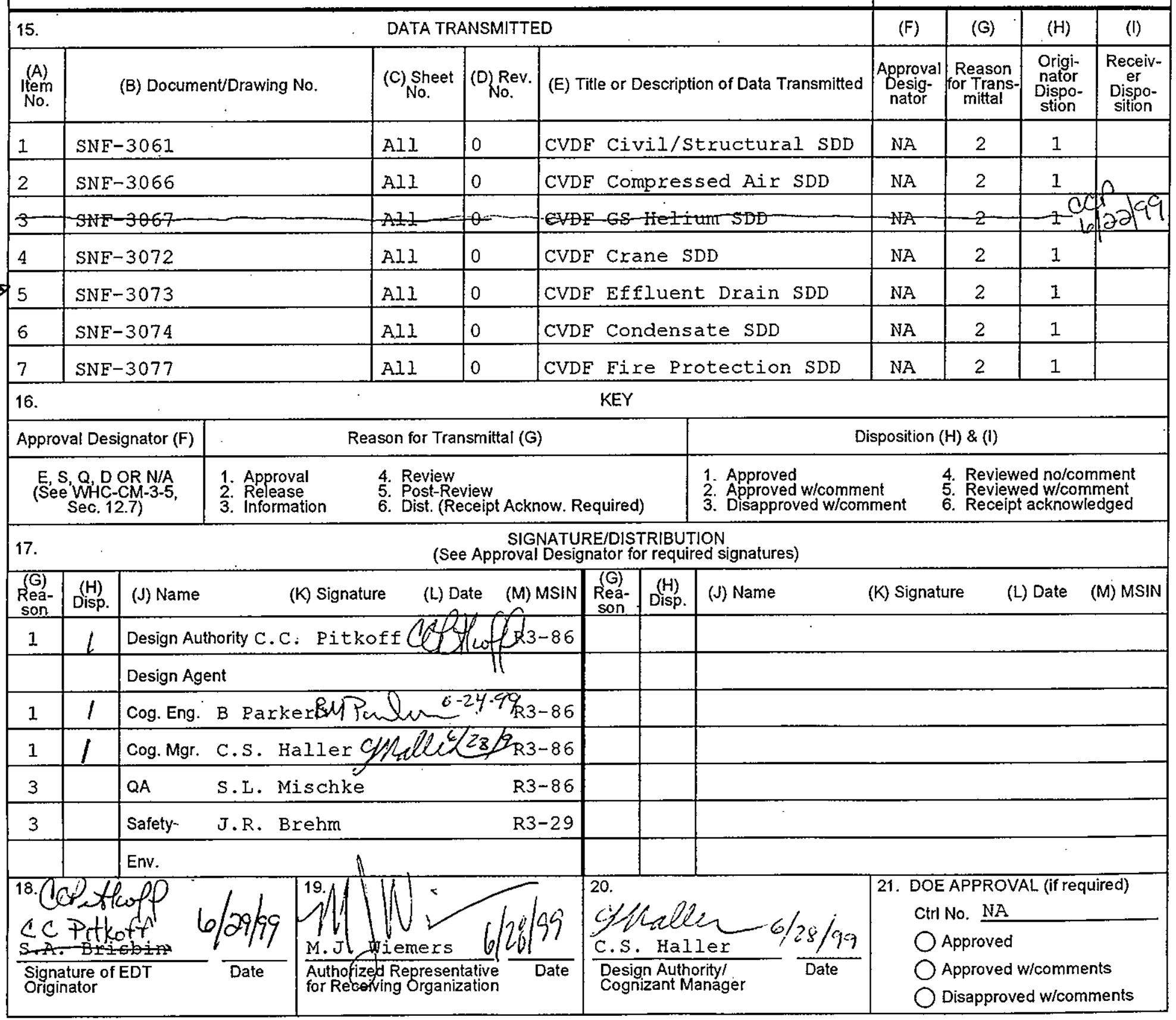




\section{Cold Vacuum Drying Facility Effluent Drain System Design Description}

C. C. Pitkoff

DE\&S Hanford,

Richland, WA 99352

U.S. Department of Energy Contract DE-AC06-96RL13200

EDT/ECN: 626308

Org Code: 2 F800

B\&R Code: 39EW70400
UC: 510

CACN: 105568

COA: A000

Total Pages: 28

Key Words: SNF, CVD, W-441, design description, effluent, floor drains

Abstract: This document describes the Cold Vacuum Drying Facility (CVDF) effluent drain system (EFS). The primary function of the EFS is to collect and transport fire suppression water discharged into a CVDF process bay to a retention basin located outside the facility. The EFS also provides confinement of spills that occur inside a process bay and allows non-contaminated water that drains to the process bay sumps to be collected until sampling and analysis are complete.

TRADEMARK DISCLAIMER. Reference herein to any specific commercial product, process, or service by trade name. trademark, manufacturer, or otherwise, does not necessarily constitute or imply its endorsement, recommendation, or favoring by the United States Government or any agency thereof or its contractors or subcontractors.

Printed in the United States of America. To obtain copies of this document. contact: Document Control Services, P.0. Box 950. Mailstop H6-08. Richland WA 99352, Phone (509) 372-2420; Fax (509) 376-4989.
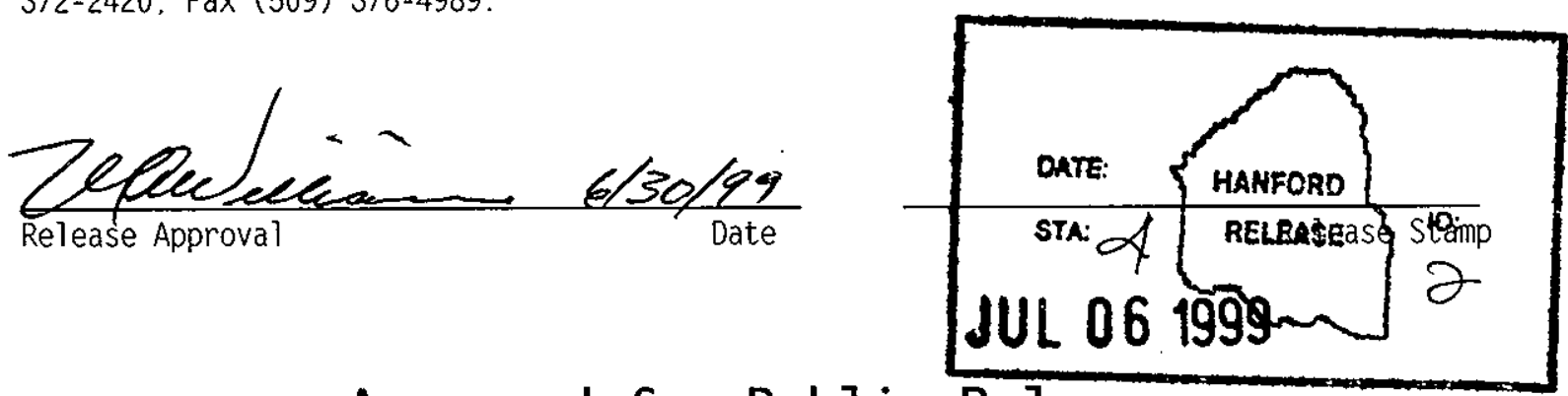

\section{Approved for Public Release}


SNF-3073 Rev. 0

COLD VACUUM DRYING FACILITY

EFFLUENT DRAINS SYSTEM

DESIGN DESCRIPTION

SYSTEM 18 


\section{TABLE OF CONTENTS}

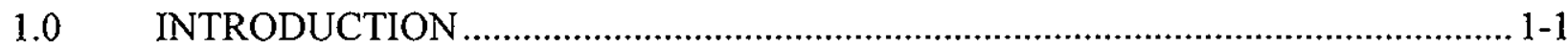

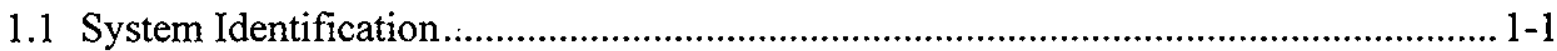

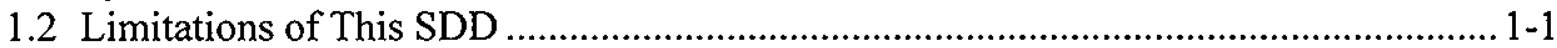

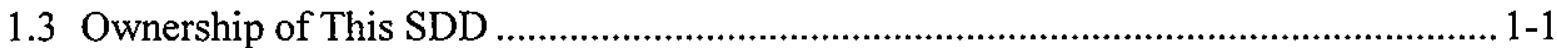

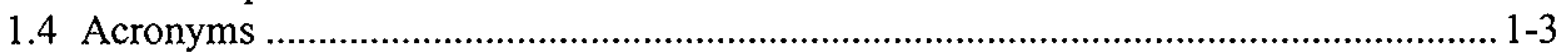

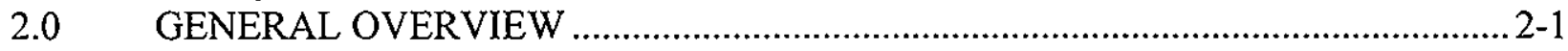

2.1 System Functions....................................................................................................... 2-1

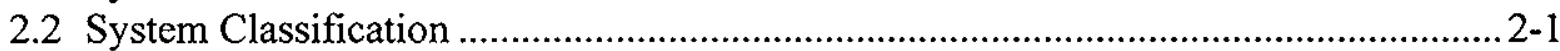

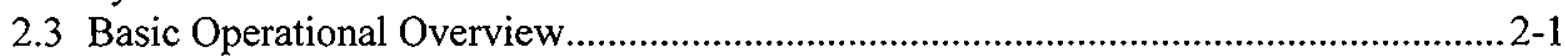

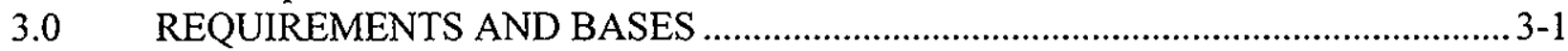

3.1 General Requirements ......................................................................................... 3-1

3.1.1 System Functional Requirements ........................................................................ 3-1

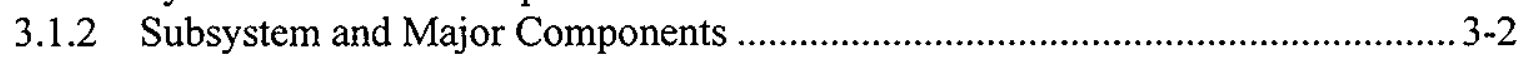

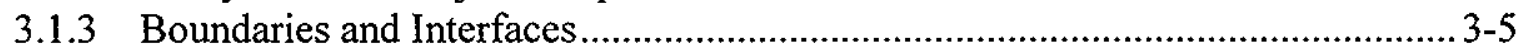

3.1.4 Codes, Standards, and Regulations .............................................................. 3-5

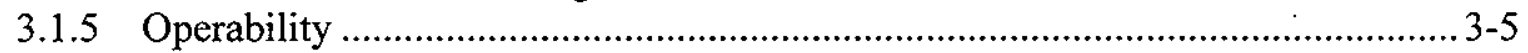

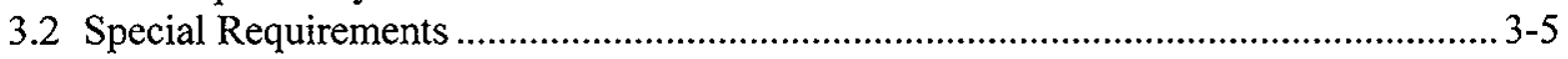

3.2.1 Radiation and Other Hazards ............................................................................

3.2.2 As Low As Reasonably Achievable (ALARA) …......................................... 3-5

3.2.3 Nuclear Criticality Safety ……………........................................................ 3-5

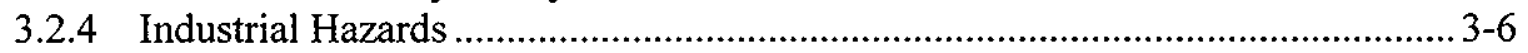

3.2.5 Operating Environment and Natural Phenomena ................................................ 3-6.

3.2.6 Human Interface Requirements .................................................................. 3-6

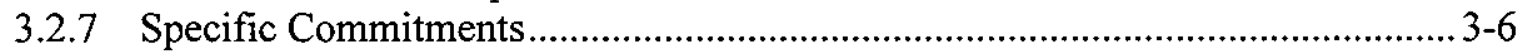

3.3 Engineering Disciplinary Requirements................................................................. 3-6

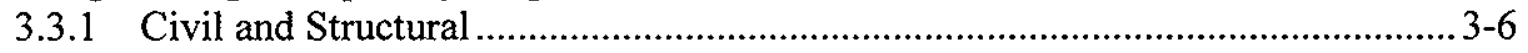

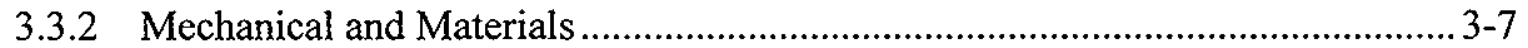

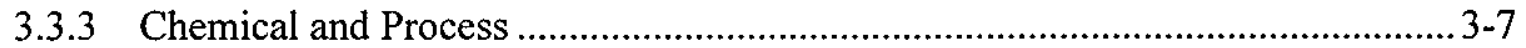

3.3.4 Electrical Power ...........................................................................................

3.3.5 Instrumentation and Control ......................................................................... 3-7

3.3.6 Computer Hardware and Software.................................................................... 3-7

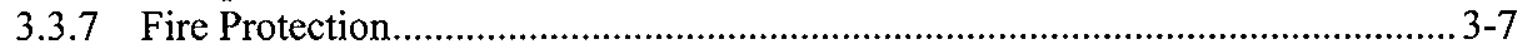

3.4 Testing And Maintenance Requirements ................................................................. 3-7

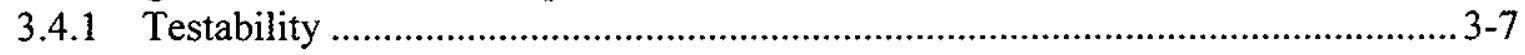

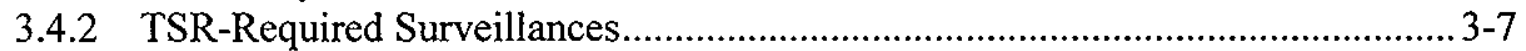

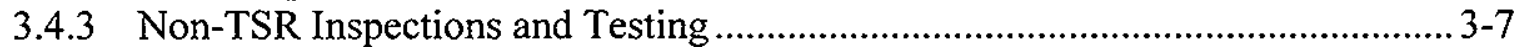

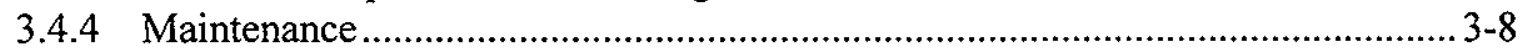

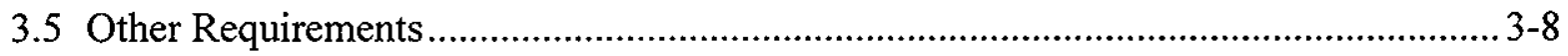

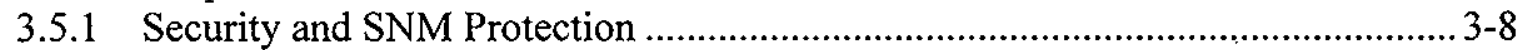

3.5.2 Special Installation Requirements................................................................... 3-8

3.5.3 Reliability, Availability, and Preferred Failure Modes...........................................3-8

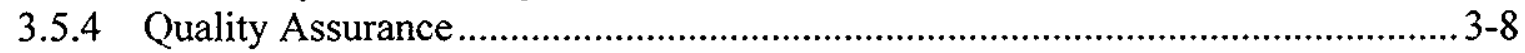

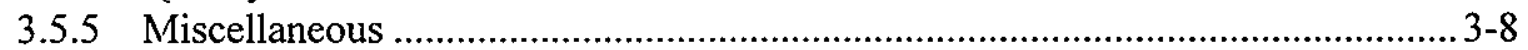

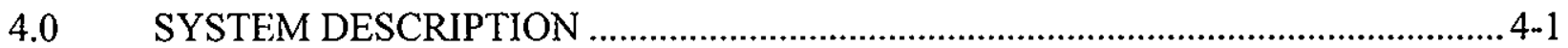




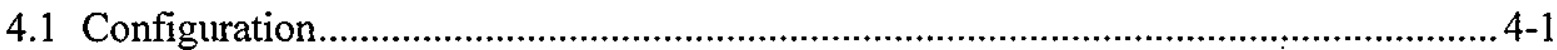

4.1.1 Description of System, Subsystems, and Major Components .............................. 4-1

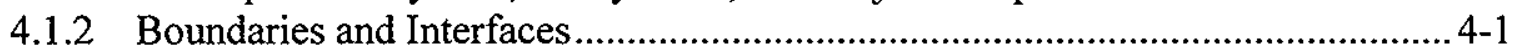

4.1.3 Physical Location and Layout....................................................................... 4-2

4.1.4 Principles of Operation ................................................................................ 4-2

4.1.5 System Reliability ............................................................................................ 4-2

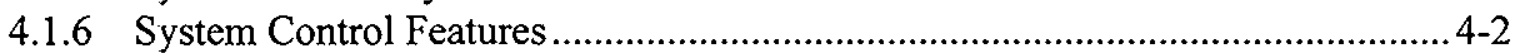

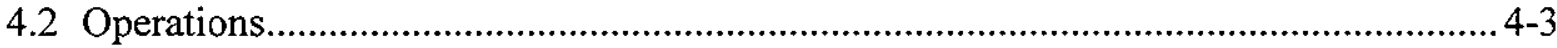

4.2.1 Initial Configurations (Pre-startup) ................................................................. 4-3

4.2.2 System Startup ......................................................................................... 4-3

4.2.3 Normal Operations.......................................................................................... 4-3

4.2.4 Off-Normal Operations ................................................................................. 4-3

4.2.5 System Shutdown ..................................................................................... 4-4

4.2.6 Safety Management Programs and Administrative Controls................................ 4-4

4.3 Testing And Maintenance.............................................................................................. 4-4

4.3.1 Temporary Configurations ........................................................................ 4-4

4.3.2 TSR-Required Surveillances.................................................................... 4-4

4.3.3 Non-TSR Inspections, and Testing .................................................................. 4-4

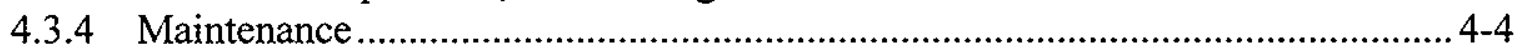


SNF-3073 Rev. 0

\section{LIST OF FIGURES}

Figure 1-1. EFS System Layout....................................................................................... 1-2

Figure 2-1. Effluent Drain System Diagram .......................................................................... 2-2 


\subsection{INTRODUCTION}

The CVD Facility provides required process systems, supporting equipment, and facilities needed for the Spent Nuclear Fuel (SNF) mission.

This system design description (SDD) addresses the effluent drain system (EFS) which supports removal of water from the process bay floors. The discussion that follows is limited to piping, valves, components, and the process bay floor drain retention basin.

\subsection{System Identification}

This SDD covers the EFS. The EFS starts at the floor drain valves in the process bay sumps ( 5 total) and ends at the retention basin located outside of the CVD Facility. Figure 1-1 shows a simplified layout for this system.

Drawing H-1-82223, CVD Facility Mechanical Utilities Drainage System P\&ID depicts the piping and instrumentation for this system.

This SDD, when used in conjunction with the other elements of the definitive design package, provides a complete picture of the EFS for the CVD Facility. Elements of SDD include functions, requirements, and descriptions. Other documents comprising the definitive design include:

- $\quad$ Project design requirements (HNF-SD-SNF-DRD-002),

- $\quad$ Fire Hazard Analysis (HNF-SD-SNF-FHA-003),

- $\quad$ Master Equipment List (SNF- 4148),

- Data and calculation matrix tracking list (SNF-3001),

- Construction Specification for Project W-441, Section 15400, Plumbing/Piping.

\subsection{Limitations of This SDD}

This SDD has been prepared with the best available information taken from approved design documents and drawings.

\subsection{Ownership of This SDD}

The CVD Design Authority assigned to the EFS system is responsible for the accuracy and technical content of this SDD. Any questions on the system or content of this document shall be resolved through the design authority. 
SNF-3073 Rev. 0

Figure 1-1. EFS System Layout

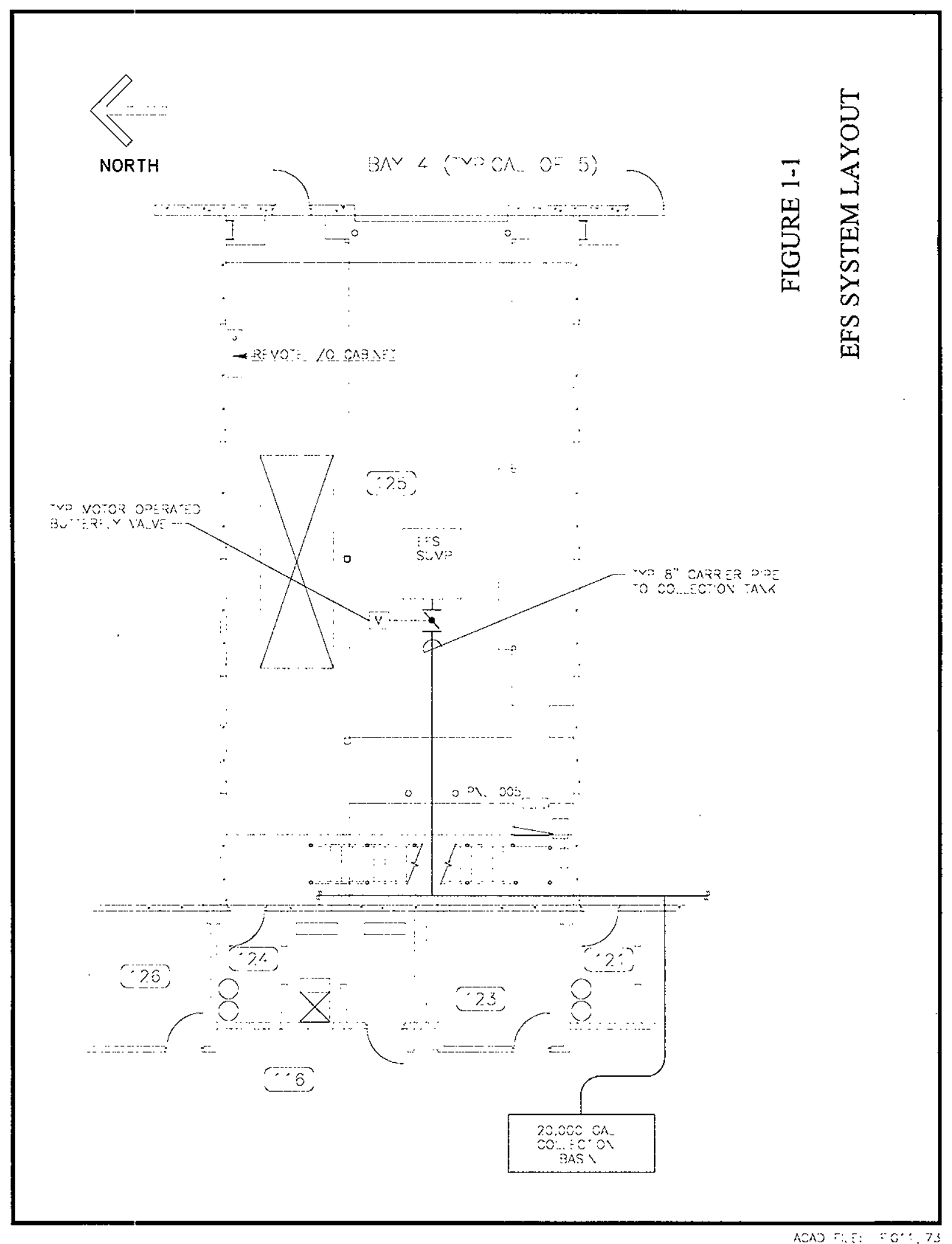


SNF-3073 Rev. 0

\subsection{Acronyms}

ALARA As Low As Reasonably Achievable

CVD Cold Vacuum Drying

EFS Effluent Drain System (liquid)

MCO Multi-Canister Overpack

PWC Process Water Conditioning

SDD System Design Description

SNF Spent Nuclear Fuel

SNM Special Nuclear Material

SSCs Systems, Structures and Components

TSR Technical Safety Requirements 
SNF-3073 Rev. 0

\subsection{GENERAL OVERVIEW}

\subsection{System Functions}

The primary function of the EFS is to collect and transport fire suppression water discharged into a CVD Facility process bay to a retention basin located outside the facility. Other functions of the EFS include the following:

- The EFS provides confinement of spills that occur inside a process bay at the CVD Facility.

- The EFS allows non-contaminated water that drains to the process bay sumps (e.g., eye wash fountain water, residual water that drains from the Multi-Canister Overpack (MCO) transportation system, etc.) to be collected until sampling and analysis are complete.

\subsection{System Classification}

All components of the EFS are designated general service. The EFS is qualified for performance category 1 as defined in DOE-STD-1020-94.

\subsection{Basic Operational Overview}

The EFS can be operated automatically or manually. Automatic operation of the system is controlled by the fire suppression system. Manual operation of the EFS is controlled by an operator from one of the Drain Valve Control Stations located in the process bays and the Retention Basin Drain Valve Control Station located outside on the north wall west of stairwell 134. Figure 2-1 illustrates the EFS.

The sump drain valves and the retention basin inlet valve are normally closed. Upon activation of the fire suppression system, the sump drain valve and the retention basin inlet valve will open automatically allowing fire suppression water to flow freely out of the process bay to the retention basin.

Operator action is required to properly dispose of non-fire suppression water collected in the process bay sumps. Water in a sump is sampled, analyzed, and verified to be either contaminated or non-contaminated. Contaminated water is removed from the sump using temporary equipment and drained to the process water system (PWC) for cleanup via the PWC system transfer line in the process bay. Water that is verified to have contamination levels less than specified limits can be drained to the retention basin. Manual draining is accomplished by turning the appropriate switch at a Drain Valve Control Station and the retention valve switch at the Retention Basin Drain Valve Control Station. 
SNF-3073 Rev. 0

Figure 2-1. Effluent Drain System Diagram

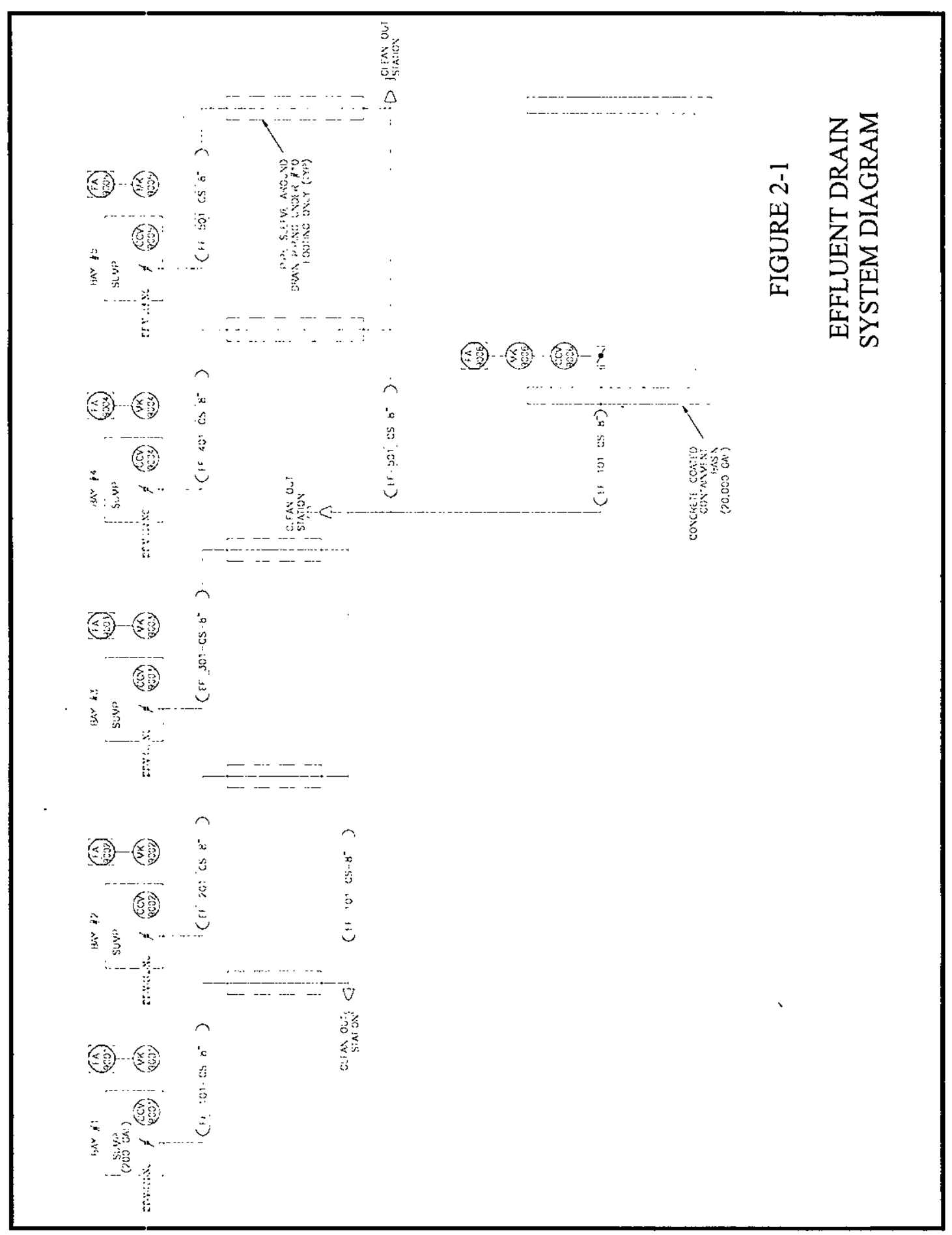

WV": $: 2 S_{-} S \backslash:-30 / 3: 2-:$ ACAD $=Z$ Z: ZSACCCO 
SNF-3073 Rev. 0

\subsection{REQUIREMENTS AND BASES}

\subsection{General Requirements}

\subsubsection{System ffunctional Requirements}

Functional requirements of the EFS system include design requirements, safety requirements, environmental requirements, mission critical requirements, and general requirements.

\subsubsection{Design Requirements}

1. Requirement: The EFS shall collect fire suppression water discharged into the process bays and automatically route to a retention basin located outside of the facility.

Basis: HNF-SD-SNF-DRD-002, Rev. 4, Section 6.6.4.6. Fire suppression water is considered potentially contaminated and must be collected to prevent a release of contamination to the environment. The system must operate automatically due to the quantity and rate of water released by the fire sprinklers. Collecting fire suppression water in a retention basin allows the water to be sampled and analyzed prior to disposal.

How the system meets the requirement: Each process bay is equipped with a sump and drain line routed to the retention basin located outside of the facility. A curb is provided around each of the process bay floors and the floors are sloped down towards the sumps. Valves in each drain line are opened automatically by the fire protection system if sprinklers are actuated; allowing fire suppression water to drain to the basin. The piping system between the process bay sumps and the retention basin is sized to drain the maximum rate that fire suppression water could be discharged into the process bay.

2. Requirement: The EFS shall collect non-firewater discharged into the process bays and allow sampling and appropriate disposal of water collected.

Basis: HNF-SD-SNF-DRD-002, Rev. 4, Section 6.6.4.6. Water released in the process bays at the CVD Facility is considered to be potentially contaminated and must be collected to prevent a release of contamination to the environment. The normally closed sump drain valve allows water in the sump to be collected, sampled, and analyzed prior to disposal. The quantity of non-firewater that may be released in the process bays allows collection in the sump.

How the system meets the requirement is met: The process bay sumps are sized to hold the maximum quantity of non-firewater that may be released into the process bays. The normally closed sump drain valves allow the water to be held until sample and analysis is complete. 


\subsubsection{Safety Requirements}

There are no safety class, safety significant, or other safety requirements for the EFS.

\subsubsection{Environmental Requirements}

1. Requirement: Floor drains shall maintain confinement between confined areas and the outdoors.

Basis: HNF-SD-SNF-DRD-002, Rev. 4, Section 6.6.4.6. Water spilled into the process bay sump is considered potentially contaminated. Therefore, the EFS must maintain confinement until the water can be sampled and verified as not contaminated. If the water is contaminated, confinement is maintained until the water is disposed of in an appropriate manner.

How the system meets the requirement: The sump drain valves are normally closed. Administrative controls will be developed and implemented to ensure that potentially contaminated water (other than fire suppression water) is not discharged to the retention basin. Each sump drain line has a grout annulus closed at both ends of the pipe sleeve with drypack.

2. Requirement: The retention basin shall be protected from the environment to prevent the spread of contamination outside of the basin.

Basis: HNF-SD-SNF-DRD-002, Rev. 4, Section 6.6.4.6. The fire suppression water discharged to the retention basin is potentially contaminated. Therefore, the basin must be provided with features to mitigate the spread of contamination outside of the basin.

How the system meets the requirement: The retention basin is coated and covered to minimize the potential to spread contamination outside of the basin.

3.1.1.4 Mission Critical Requirements. There are no mission critical requirements associated with this system.

3.1.1.5 General Requirements. There are no specific general requirements not covered by other requirements in this document.

\subsubsection{Subsystem and Major Components}

1. Requirement: Each process bay shall have floor drains routed to a retention basin located outside of the facility.

Basis: See Requirement 1 in Section 3.1.1.1. 
SNF-3073 Rev. 0

How the system meets the requirement: See Requirement 1 in Section 3.1.1.1.

2. Requirement: The initial $757 \mathrm{~L}$ ( $200 \mathrm{gal})$ of non-firewater released into the process bay shall be collected in a floor sump (1 each per process bay).

Basis: HNF-SD-SNF-DRD-002, Rev. 4, Section 6.6.4.6. In the event of a process system failure, an entire batch of $\mathrm{MCO}$ water must be collected for disposal as radiologically contaminated liquid.

How the system meets the requirement: The sump in the process bay floor is sized to hold an entire batch of MCO water in the event of a process system failure. The process bay floors are sloped downward towards the sumps.

3. Requirement: Water collected in a process bay sump during an off-normal event (contaminated) or during normal activities (e.g., rainwater from tires) shall be sampled and disposed of in an appropriate manner.

Basis: See Requirement 2 in Section 3.1.1.1.

How the system meets the requirement: See Requirement 2 in Section 3.1.1.1.

4. Requirement: Design of the facility floors and floor drains shall prevent the buildup and spill of water out of the CVD Facility when fire protection sprinklers are discharged at the maximum rate.

Basis: See Requirement 1 in Section 3.1.1.1.

How the system meets the requirement: See Requirement 1 in Section 3.1.1.1.

5. Requirement: The sump drain valve(s) and retention basin inlet valve must open automatically upon actuation of the fire suppression system in a particular process bay(s).

Basis: HNF-SD-SNF-DRD-002, Rev. 4, Section 6.6.4.6. If the fire suppression system is actuated, water must be drained from the sumps to prevent the process bay from overflowing and releasing potentially contaminated water to the environment.

How the system meets the requirement: The sump drain valves and the retention basin inlet valve are interlocked with the fire protection system to open upon actuation of the fire suppression system. Drain lines to the retention basin are designed to allow the maximum flow rate of fire suppression water to be directed to the basin. 
6. Requirement: The process bay sumps shall have drain valves that do not drain water automatically unless activated by the fire protection sprinkler system.

Basis: HNF-SD-SNF-DRD-002, Rev. 4, Section 6.6.4.6. Water collected in the process bay sumps may be potentially contaminated. Therefore, sump water must be sampled to determine the appropriate disposal method.

How the system meets the requirement: The inlet valve to the retention basin and the drain valves in the process bay sumps are normally closed and will not open automatically unless actuated by the fire suppression system. Operating procedure will direct operators to sample and dispose of water appropriately.

7. Requirement: The drain piping shall be routed to a retention basin with monitoring capability to detect a spill discharge occurrence.

Basis: HNF-SD-SNF-DRD-002, Rev. 4, Section 6.6.4.6. Water collected in the process bay sumps is considered potentially contaminated; therefore, the operators must be informed when water is in the sumps.

How the system meets the requirement: A moisture sensor is provided in each sump to detect liquid.

8. Requirement: The retention basin shall include a means to allow sampling and pumping of water in the basin to a tanker truck.

Basis: HNF-SD-SNF-DRD-002, Rev. 4, Section 6.6.4.6. Fire suppression water is considered potentially contaminated and therefore must be sampled to determine the appropriate method of disposal.

How the system meets the requirement: The design of the retention basin allows sampling of basin water and the use of temporary pumping equipment to empty the basin. Recovery procedures will direct that water collected in the retention basin be sampled and pumped to a tanker truck as either contaminated or non-contaminated liquid as determined by sample results.

9. Requirement: The retention basin shall have an epoxy-based coating on all interior surfaces.

Basis: HNF-SD-SNF-DRD-002, Rev. 4, Section 6.6.4.6. The epoxy-based coating on the interior surfaces of the retention basin will help prevent basin leaks and facilitate basin decontamination.

How the system meets the requirement: The design of the retention basin requires that interior surfaces be coated with an epoxy-based coating. 
SNF-3073 Rev. 0

\subsubsection{Boundaries and Interfaces}

There are no specific requirements with respect to system boundaries and interfaces. This system interfaces with the facility as a whole. The facility requirements are identified in Civil/Structural System (SDD-SNF-3061).

\subsubsection{Codes, Standards, and Regulations}

\subsubsection{Code of Federal Regulations}

- $\quad 10$ CFR 830.120, "Quality Assurance"

- $\quad 29$ CFR 1910.120, "Occupational Safety and Health Standards."

\subsubsection{American Society of Mechanical Engineers Codes}

- $\quad$ ANSI/ASME, B16, Standard series, 1996, Fittings, Flanges and Valves, American Society of Mechanical Engineers, New York, New York.

- $\quad$ ANSI/ASME, B31.3, 1995, Power Piping Code, American Society of Mechanical Engineers, New York, New York.

- $\quad$ ANSI/ASME, B31.9, 1996, Building Services Piping, American Society of Mechanical Engineers, New York, New York.

\subsubsection{Operability}

There are no operability requirements for the EFS.

\subsection{Special Requirements}

\subsubsection{Radiation and Other Hazards}

There are no requirements related to radiation or other hazards for the EFS.

\subsubsection{As Low As Reasonably Achievable (ALARA)}

There are no AL,ARA requirements specific to the EFS.

\subsubsection{Nuclear Criticality Safety}

1. Requirement: The process bay collection sumps shall be critically safe.

Basis: HNF-SD-SNF-DRD-002, Rev. 4, Section 6.6.4.6. An entire batch of $\mathrm{MCO}$ water may be collected in the sump if a process system failure occurs. 
How the system meets the requirement: Criticality control is met by the designing the sumps in the bay floors to be critically safe as required by the Spent Nuclear Fuel Project Cold Vacuum Drying Facility Design Requirements Document, HNF-SD-SNF-DRD-002, Rev. 4. A criticality safety evaluation report for CVD Facility has been prepared (see HNF-SDSNF-CSER-006).

\subsubsection{Industrial Hazards}

There are no requirements related to industrial hazards for the EFS.

\subsubsection{Operating Environment and Natural Phenomena}

1. Requirement: The EFS shall function under the phenomena identified in DOE-STD1020-94, Natural Phenomena Hazards Design and Evaluation Criteria for Department of Energy Facilities and DOE Order 5480.28, Natural Phenomena Hazards Mitigation including the worst winter weather conditions.

Basis: Since the facility must operate on a continuous basis, and since during facility operation a discharge to this system is possible, this system must be capable of supporting continuous operation.

How the system meets the requirement: The EFS is designed according to criteria identified in the above listed references. Drain lines are sloped downward to prevent the accumulation and freezing of liquids during winter operations

\subsubsection{Human Interface Requirements}

There are no human interface requirements for the EFS.

\subsubsection{Specific Commitments}

1. Requirement: All aspects of the EFS shall be in compliance with the Hanford Federal Facility Agreement and Consent Order (Ecology 1994) and applicable federal, state, and local laws and American Indian treaty rights.

Basis: Site Agreement and State/Federal Law.

How the system meets the requirement: The design and construction and operation of the facility (including this system) have incorporated all aspects of these documents. Issuance of the operating permit confirms compliance.

\subsection{Engineering Disciplinary Requirements}

\subsubsection{Civil and Structural}


SNF-3073 Rev. 0

The EFS is qualified for performance category 1 as defined in DOE-STD-1020-94.

\subsubsection{Mechanical and Materials}

All piping and valves in the EFS are designated general service and are designed and tested in accordance with ANSI/ASME B31.9, Building Services Piping.

\subsubsection{Chemical and Process}

There are no chemical or process requirements associated with the EFS.

\subsubsection{Electrical Power}

The sump drain valves and the retention basin inlet valve requires $120 \mathrm{VAC}$, single-phase power. The power is supplied from the circuit breaker panels provided as part of the electrical systems.

\subsubsection{Instrumentation and Control}

The sump drain valves and the retention basin inlet valve are required to open when a signal is received from the fire alarm control panel.

\subsubsection{Computer Hardware and Software}

There are no computer hardware or software engineering requirements for the EFS.

\subsubsection{Fire Protection}

There are no fire protection requirements for the EFS. Fire protection is supported by the overall building fire protection system and is covered in a separate SDD (see SNF-3077, Cold Vacuum Drying Facility Fire Protection System Design Description).

\subsection{Testing And Maintenance Requirements}

\subsubsection{Testability}

There are no unique testing requirements for the EFS.

\subsubsection{TSR-Required Surveillances}

There are no surveillances required by TSRs for the EFS.

\subsubsection{Non-TSR Inspections and Testing}

1. Requirement: Automatic operation of the sump drain valves and the retention basin inlet valve shall be tested when the fire suppression system is tested by the Fire Department. 
SNF-3073 Rev. 0

Basis: See Requirement 1 in Section 3.1.1.1.

How the system meets the requirement: See Requirement 1 in Section 3.1.1.1.

\subsubsection{Maintenance}

There are no maintenance requirements for the EFS.

\subsection{Other Requirements}

\subsubsection{Security and SNM Protection}

There are no security or special nuclear material (SNM) requirements for the EFS.

\subsubsection{Special Installation Requirements}

There are no special installation requirements for the EFS.

\subsubsection{Reliability, Availability, and Preferred Failure Modes}

Requirement: The sump drain valves and the retention basin inlet valve shall fail in the closed position.

Basis: HNF-SD-SNF-DRD-002, Rev. 4, Section 6.6.4.6. The sump drain valves and retention basin inlet valve will fail in the closed position to prevent discharging contaminated water to the basin.

How the system meets the requirement: The sump drain valves and retention basin inlet valve are normally closed valves that are energized to open. These valves remain closed upon loss of electrical power.

\subsubsection{Quality Assurance}

The EFS fabrication quality assurance/control program is based on the safety classification of the SSC's as detailed in the Spent Nuclear Fuel Project Cold Vacuum Drying Facility Master Equipment List, SNF-4148, and application of a graded approach as described in the Project Hanford Quality Assurance Program Description, HNF-MD-599.

\subsubsection{Miscellaneous}

A conceptual decontamination and decommissioning plan for the CVDF, as identified in the guidelines of DOE-STD-3009-94, Preparation Guide for U.S. Department of Energy Nonreactor Nuclear Facility Safety Analysis Reports, is included in HNF-SD-SNF-SAR-002. 
SNF-3073 Rev. 0

\subsection{SYSTEM DESCRIPTION}

The system description and operations presented in this section discuss those system features that satisfy the functional requirements listed in Section 3.0. The process bay sumps are not considered to be within the boundary of the EFS; therefore, discussion of the sumps is limited to that necessary to describe the EFS.

\subsection{Configuration}

\subsubsection{Description of System, Subsystems, and Major Components}

The major components of the EFS include the five process bay sump drain valves, the retention basin inlet valve, the retention basin, and the associated drain pipelines between the valves. A simple diagram of the EFS is provided in Figure 2-1.

The sump drain valves and the retention basin inlet valve are 8-inch, flanged, butterfly-type valves with electric actuators. The valves are Keystone ${ }^{\circledR}$ Figure AR2-064 with tapped lugs. The valves are fitted with Keystone ${ }^{\circledR}$ Model 777 EPI-36 electric actuators (120VAC). The valves are designed to fail in the closed position.

The drain lines between the sump drain valves and the retention basin inlet valve are 8 -inch carbon steel pipe. Flanged ends are provided for easy removal and installation of valves. Clean-outs are provided at all bends.

The retention basin is located outside the CVD Facility. The retention basin will hold a maximum of 20,000 gallons.

\subsubsection{Boundaries and Interfaces}

The sump drain valves in CVD Facility process bays $1,2,3,4$, and 5 and the retention basin outside the building bound the EFS. The EFS interfaces with the fire alarm system, the Drain Valve Control Stations, the Retention Basin Drain Valve Control Station, and the electrical panels indicated below.

\begin{tabular}{|c|c|c|}
\hline Bay Number & Panel Number & Circuit Number \\
\hline 1 & 2 & 20 \\
\hline 2 & 4 & 20 \\
\hline 3 & 6 & 20 \\
\hline 4 & 8 & 20 \\
\hline 5 & 10 & 20 \\
\hline Basin Inlet Valve & 11 & 10 \\
\hline
\end{tabular}




\subsubsection{Physical Location and Layout}

The sumps are located in the center of each process bay floor inside the CVD Facility. The sumps are at a low point in the floor. The process bay floors slope down towards the sumps to facilitate draining. The 8-inch sump drain lines route liquid from each sump to the retention basin located outside of the building.

\subsubsection{Principles of Operation}

The EFS is used to collect fire suppression water discharged into the process bays and automatically route that water to the retention basin. Upon activation of the fire suppression system in one of the process bays, the sump drain valve for that process bay and the retention basin inlet valve open automatically. Water will then drain to the retention basin from the sump.

The EFS is also used to drain acceptable liquid collected in the process bay sumps to the retention basin. Water is considered acceptable if it is non-radiologically contaminated. Other than fire suppression water, all water discharged to the retention basin must be sampled, analyzed, and verified to be non-contaminated. The sump drain valves function as contamination control valves by preventing the discharge of water to the retention basin until that water is determined by analysis to be acceptable.

Once liquid in a sump is determined to be acceptable, that sump can be drained manually to the retention basin. The operator manually drains the sump by actuating of the appropriate switch at the Drain Valve Control Station and at the Retention Basin Drain Valve Control Station.

Water collected in the retention basin is sampled and analyzed prior to disposal. After analysis, the water in the basin is pumped to a tanker truck as contaminated or non-contaminated liquid using temporary equipment. The tanker truck is described in the "Special Equipment SDD," SNF-3076.

\subsubsection{System Reliability}

The drain valve in each sump is a normally closed valve that requires electric power to open. Likewise, the valve in the entrance to the retention basin is a normally closed valve similar to the drain valves in the sumps and requires electrical power open. This system must support the overall reliability of the CVD. Procuring and installing the equipment to the referenced codes and standards will provide adequate reliability, therefore, no special features or considerations are required.

\subsubsection{System Control Features}

4.1.6.1 System Monitoring. There is no capability to monitor the status of the EFS in the system design. An operator must visually verify the sump drain and basin inlet valves are in the correct position. 
4.1.6.2 Control Capability and Location. The sump drain valves and the retention basin inlet valve are opened automatically when a signal is received from the Fire Alarm Control Panel. The panel containing the control relays is located next to the Fire Alarm Control Panel.

Manual control of the EFS contamination control valves is performed at the Drain Valve Control Station located on the north wall in each bay to manually open any sump valve. Manual control of the EFS retention basin inlet valve is performed at the Retention Basin Drain Valve Control Station located on the outside west wall north of stairwell 134.

4.1.6.3 Automatic and Manual Actions. The sump valves and retention basin valve must open automatically when the fire suppression system actuates. All other actions are manually performed.

4.1.6.4 Setpoints and Ranges. There are no setpoints or ranges associated with the EFS.

4.1.6.5 Interlocks, Bypasses, and Permissives. The sump drain valves and retention basin inlet valve are interlocked with the fire suppression system. There are no bypasses associated with the EFS. A manual permissive is provided to manually open any of the sump drain valves and the retention basin inlet valve without actuating the fire suppression system.

\subsection{Operations}

\subsubsection{Initial Configurations (Pre-startup)}

A test specification will be developed identifying the requirements for all testing associated with this system. This specification will address factory acceptance tests (FATS), construction acceptance tests (CATS), and pre-startup tests.

\subsubsection{System Startup}

Startup, alignment, prerequisite testing, and formal start up activities will be identified in the test specification.

\subsubsection{Normal Operations}

Normal operation of the EFS is described in Section 4.1.4.

Operational procedures providing detailed information on operating modes and activities (including alarm response, shutdown, etc.) will be developed.

\subsubsection{Off-Normal Operations}

The only identified off-normal event would be if the fire suppression system fails to turn off after initiation. This event would eventually cause the retention basin to overflow. Manual intervention is required in this case, and the appropriate actions will be identified in the alarm response procedures. 
SNF-3073 Rev. 0

\subsubsection{System Shutdown}

There are no special system shutdown requirements for the EFS.

\subsubsection{Safety Management Programs and Administrative Controls}

The necessary administrative controls procedures will be developed and incorporated into the operating procedures to prevent manually draining contaminated water from a sump to the retention basin.

These controls and procedures will be in accordance with the Spent Fuel Integrated Safety Management Plan.

\subsection{Testing And Maintenance}

\subsubsection{Temporary Configurations}

There are no temporary configurations for the EFS.

\subsubsection{TSR-Required Surveillances}

There are no TSR-required surveillances associated with the EFS.

\subsubsection{Non-TSR Inspections, and Testing}

There are no testing or inspection requirements for the EFS.

\subsubsection{Maintenance}

There is no unique maintenance required due to the system design and short facility life. Maintenance procedures will be developed to address routine maintenance requirements. 
SNF-3073 Rev. 0

Appendix A

Source Documents

A-1 
HNF-3553, Spent Nuclear Fuel Project Final Safety Analysis Report, Annex B, "Cold Vacuum Drying Facility Final Safety Analysis Report", DRAFT, DE\&S Hanford, Incorporated, Richland, Washington.

HNF-MD-599, Project Hanford Quality Assurance Program Description, Fluor Daniel Hanford, Incorporated, Richland, Washington.

HNF-SD-SNF-DRD-002, 1999, Cold Vacuum Drying Facility Design Requirements, Rev. 4, DE\&S Hanford, Incorporated, Richland, Washington.

SNF-3001, 1999, Spent Nuclear Fuel Project Cold Vacuum Drying Facility Calculation Database, Rev. 0, DE\&S Hanford, Richland, Washington.

SNF-4148, 1999, Spent Nuclear Fuel Project Cold Vacuum Drying Facility Master Equipment List, Rev. 6, DE\&S Hanford, Richland, Washington. 
SNF-3073 Rev. 0

Appendix B

System Drawings

B-1 
SNF-3073 Rev. 0

\section{General/Architectural/Structural Drawings}

H-1-82090, Drawing List and Vicinity Map

H-1 -82092, Civil Site Plan, Legend

H-1-82101, Architectural First Floor Plan

H-1-82121, Structural Foundation Plan

H-1-82122, Structural Foundation Sections \& Details

\section{Mechanical/Piping Drawings}

H-1-82225, Mechanical utilities drainage system P\&ID

H-1-82223, Mechanical utilities $1^{\text {st }}$ floor drainage system P\&ID

H-1-82229, Mechanical utilities sections \& details

\section{Electrical Drawings}

H-1-82244, Electrical first floor fire alarm

H-1-82247, Sheets 2 \&3, CDVF Electrical, Process Bay Panel Schedules

\section{Specification List}

W-441-C1, Construction Specification for Cold Vacuum Drying Facility, Richland, Washington 
SNF-3073 Rev. 0

Appendix C

System Procedures

C-1 
SNF-3073 Rev. 0

Operating procedures will be developed in the future. 


\section{DISTRIBUTION SHEET}

\begin{tabular}{|c|c|c|c|c|c|}
\hline \multirow{2}{*}{$\begin{array}{l}\text { To } \\
\text { Distribution }\end{array}$} & \multirow{2}{*}{\multicolumn{3}{|c|}{$\begin{array}{l}\text { From } \\
\text { Technical Integration }\end{array}$}} & \multicolumn{2}{|l|}{ Page 1 of 1} \\
\hline & & & & \multicolumn{2}{|c|}{ Date June 14,1999} \\
\hline \multirow{2}{*}{\multicolumn{4}{|c|}{$\begin{array}{l}\text { Project Title/Work Order EDT-626313 } \\
\text { SNF-3061, SNF-3066, SNF-3067) SNF-3072, SNF-3073, SNF-3074, } \\
\text { SNF-3077( SNF-3078, SNF-3079, SNF-3080, SNF-3081) on EDT-626311 }\end{array}$}} & \multirow{2}{*}{\multicolumn{2}{|c|}{$\begin{array}{l}\text { EDT No. } 626308 \\
\text { ECN No. NA }\end{array}$}} \\
\hline & & & & & \\
\hline Name & MSIN & $\begin{array}{l}\text { Text } \\
\text { With All } \\
\text { Attach. }\end{array}$ & Text Only & $\begin{array}{l}\text { Attach./ } \\
\text { Appendix } \\
\text { Only }\end{array}$ & $\begin{array}{c}\text { EDT/ECN } \\
\text { Only }\end{array}$ \\
\hline W. C. Alaconis & R3-86 & $\mathrm{X}$ & & & \\
\hline L. L. Blehm & X3-86 & $\mathrm{X}$ & & & \\
\hline K. A. Boes & R3-86 & $\mathrm{X}$ & & & \\
\hline J.R. Brehm & R3-86 & $\mathrm{X}$ & & & \\
\hline C. S. Haller & R3-11 & $\mathrm{X}$ & & & \\
\hline L. C. McKenzie & S2-45 & $\mathrm{X}$ & & & \\
\hline S. L. Mischke & $\mathrm{R} 3-86$ & $\mathrm{X}$ & & & \\
\hline C. C. Pitkoff & R3-86 & $\mathrm{X}$ & & & \\
\hline CVD Project File & R3-86 & $\mathrm{X}$ & & & \\
\hline SNF Project File & R3-11 & $\mathrm{X}$ & & & \\
\hline
\end{tabular}

